\title{
ANALYSIS OF POSSIBILITIES OF THE DIGITAL TECHNOLOGIES USE IN TEACHING FOREIGN LANGUAGES
}

\author{
[ANALYZA MOZNOSTI VYUZIVANIA DIGITALNYCH \\ TECHNOLOGII VO VYUCOVANI CUDZICH JAZYKOV]
}

\author{
Adriana Nagyova
}

\section{doi: 10.18355/PG.2016.5.1.101-112}

\begin{abstract}
The paper deals with the possibilities of the implementation of digital technologies in teaching English language at lower secondary level of education (ISCED 2). In order to evaluate our findings, we applied a quantitative research method. As a tool for collecting research data, we used a specially designed questionnaire. Through respondents' answers to the questionnaire items P1 to P6, we assessed the attitudes and opinions of students, and we found the answer to the question, what are the attitudes of students towards the acquisition of the English language through digital technologies at given level of education.
\end{abstract}

\section{Key words}

digital technologies, lower secondary level of education. English teaching subject, language skills, questionnaire

\section{Anotácia}

Príspevok sa zaoberá problematikou využívania digitálnych technológií vo vyučovaní anglického jazyka na nižšom sekundárnom stupni vzdelávania (ISCED 2). Na vyhodnotenie jednotlivých zistení bola použitá kvantitatívna výskumná metóda, v rámci ktorej sme ako nástroj zberu výskumných údajov použili špeciálne vytvorený dotazník. Prostredníctvom odpovedí respondentov na dotazníkové položky P1 až P6 sme hodnotili postoje a názory žiakov, pričom sme našli odpovede na otázky, aké sú postoje žiakov k osvojovaniu si anglického jazyka prostredníctvom digitálnych technológií na sledovanom stupni vzdelávania.

\section{Kl'účové slová}

digitálne technológie, nižší sekundárny stupeň vzdelávania, vyučovací predmet anglický jazyk, jazykové zručnosti, dotazník

\section{Úvod}

$\mathrm{V}$ informačnej spoločnosti založenej na vedomostiach sa digitálne technológie stávajú bežnou súčast'ou života, prenikajú do každej oblasti l'udskej činnosti, výchovu a vzdelávanie nevynímajúc. Dnes už nikto nepochybuje o potrebe integrovat' moderné digitálne technológie do vyučovacieho procesu na každom stupni vzdelávacieho systému. Vd'aka 
vysokej miere interaktivity, spätnej väzby a rôznej funkcionality, sú digitálne technológie úžasným nástrojom pre experimentovanie, objavovanie a hranie sa zároveň. Implementácia moderných technológií do výučby anglického jazyka umožňuje žiakom pracovat' $\mathrm{s}$ jazykom v autentickom kontexte.

Ciel'om výučby a učenia sa cudzieho jazyka je získanie štyroch základných jazykových zručností: počúvanie, čítanie, písanie a rozprávanie. S modernými digitálnymi technológiami sú žiaci motivovaní k štúdiu, získavaniu nových informácií a zároveň zlepšujú a posilňujú uvedené jazykové zručnosti. Technologicky bohaté prostredie samo o sebe nie je zárukou kvalitného využitia digitálnych technológií na podporu poznávacieho procesu žiaka. Skúsenosti z rôznych zahraničných i domácich výskumných projektov a štúdií nás upozorňujú na to, že samotná prítomnost' nových technológií nezaručuje produktívne využitie ich potenciálu. Ovel'a dôležitejším faktorom je kvalitná pedagogická práca pedagóga odzrkadl'ujúca ich uvážlivé používanie pre učenie sa v konkrétnych situáciách.

V príspevku sa venujeme analýze možností využitia digitálnych technológií vo výučbe anglického jazyka na úrovni nižšieho sekundárneho stupňa vzdelávania.

\section{Digitálne technológie vo vyučovaní anglického jazyka a ich vplyv na rozvoj jazykových zručností}

Tradičné metódy vyučovania sa s určitými zmenami zachovali až dodnes a stále spĺn̆ajú nezastupitel'nú úlohu v spoločnosti. V súčasnom vzdelávaní však dominuje snaha o využitie nových metód a foriem výučby realizovaných prostredníctvom digitálnych technológií, ktorých implementácia do výučby a ich vhodné využitie môže byt' prínosom pre celý edukačný proces. Elektronické médiá prinášajú rozmanité spôsoby ako ich využit' v procese výučby s prínosom ako pre žiaka, tak aj pre pedagóga. Vo vyučovacom procese žiaci základných škôl pod vedením učitel'a spoznávajú realitu v najrozmanitejších podobách. Výsledkom tohto poznávania sú vedomosti, zručnosti a návyky, tiež rôzne postoje a spôsob správania sa. Všetky javy však nemožno priblížit' len slovne či opisom, a preto je úlohou učitel'a vybrat' také prostriedky, ktoré približujú to, čo je vol'ným okom neviditel'né, nedostupné, sprehl'adňujú to, čo je príliš zložité a konkretizujú to, čo je abstraktné. Názornost' dosiahnutá používaním elektronických prostriedkov, napríklad v podobe jazykových laboratórií, počítačov, interaktívnej tabule, rôznych výučbových softvérov, či digitálnych hračiek ul'ahčuje žiakom vytváranie predstáv, rozvíja u nich jazykové zručnosti a napomáha k lepšiemu zapamätávaniu si učiva. Takéto prostriedky prispievajú aj pohotovejšiemu vybavovaniu si poznatkov, k ich presnejšej reprodukcii a lepšej aplikácii v každodennej praxi.

Základnou úlohou komunikačného vyučovania je rozvíjat' komunikačné zručnosti žiakov, ktoré rozdel'ujeme do dvoch vel'kých oblastí (Palencarova - Kesselova - Kupcova In Marciova, 2011). 
Tabul'ka 3 Rozdelenie komunikačných zručností žiakov

\begin{tabular}{|l|ll|}
\hline $\begin{array}{l}\text { Receptívne komunikačné zručnosti } \\
\text { (oblast' vnímania) }\end{array}$ & $\begin{array}{l}\text { počúvanie } \\
\text { čítanie }\end{array}$ & procesy pochopenia \\
\hline $\begin{array}{l}\text { Produktívne komunikačné zručnosti } \\
\text { (oblast' vyjadrovania) }\end{array}$ & $\begin{array}{l}\text { rozprávanie } \\
\text { písanie }\end{array}$ & tvorivé procesy \\
\hline
\end{tabular}

Pretože žiaci potrebujú pomoc pri nadobúdaní jednotlivých zručností, učitel' môže použit' rôzne dostupné digitálne technológie, ktoré ul'ahčujú učenie sa a zároveň sa zameriavajú na rozvoj jazykových zručností.

\section{Metodológia výskumu}

\section{Ciel' a predmet výskumu}

V príspevku sme preto analyzovali aktuálny stav v oblasti implementácie elektronickej podpory vzdelávania do vyučovania predmetu anglický jazyk na nižšom sekundárnom stupni vzdelávania. Preštudovali sme pomerne vel'ké množstvo literárnych zdrojov, kde boli uvedené príklady úspešnej implementácie digitálnych technológií do výchovno-vzdelávacieho procesu anglického jazyka na sledovanom vzdelávacom stupni. Uvádzané príklady taktiež ukázali, že digitálne technológie sú pre žiakov vel'mi efektívne a atraktívne. My sme sa v tejto súvislosti zaujímali o to, či táto skutočnost' bude mat' rovnaký alebo podobný rozmer aj u slovenských žiakov. V súvislosti s hl'adaním odpovedí na toto tvrdenie sme si stanovili nasledovné výskumné otázky:

Považujú žiaci nižšieho sekundárneho stupňa vzdelávania digitálne technológie používané na hodinách anglického jazyka za dostatočne zaujímavé a atraktívne?

Ulahčujú digitálne technológie používané na hodinách anglického jazyka žiakom nižšieho sekundárneho stupňa vzdelávania pochopenie preberaného učiva?

Odpovede na tieto otázky sme získali vyhodnotením a následnou analýzou odpovedí respondentov distribuovaného dotazníka.

Ciel'om výskumu bolo zistit' názory žiakov nižšieho sekundárneho stupňa vzdelávania na implementáciu digitálnych technológií do vyučovania anglického jazyka z pohl'adu vybraných aspektov.

Ako východisko pre spracovanie praktickej časti záverečnej práce nám slúžili teoretické poznatky, štúdium dostupnej literatúry, rôznorodé informačné zdroje a v podstatnej miere i osobné hodnotenia a postoje respondentov k problematike zavádzania elektronickej podpory vzdelávania $\mathrm{v}$ predmete anglický jazyk.

\section{Charakteristika výskumnej vzorky}

Vzhl'adom na skutočnost', že základy schopností a zručností, vrátane kl’účových kompetencií žiaka, ako aj prvá orientácia mladých l’udí $\mathrm{k}$ budúcemu povolaniu sa vytvárajú najmä počas povinnej školskej 
dochádzky, sme sa v našom výskume zamerali na nižší sekundárny stupeň vzdelávania.

Podmienkou realizácie výskumných aktivít bolo nájst' školu, ktorá bude disponovat' dostatočným materiálno-technickým vybavením $\mathrm{v}$ podobe digitálnych technológií vhodných pre podporu výučby anglického jazyka. Následne po uskutočnených rozhovoroch s učitel'mi, boli konkretizované digitálne pomôcky, ktoré má škola $\mathrm{v}$ tejto oblasti $\mathrm{k}$ dispozícii. Základná škola, sv . Michala 42, Levice je dobre vybavenou školou, ktorá má dostatočné zázemie, učebne vybavené s počítačmi, interaktívnymi tabul'ami, dataprojektormi, rovnako sa v nej nachádza i moderné jazykové laboratórium. Učitelia vyučujú svojich žiakov prostredníctvom internetu a rôznych typov elektronických virtuálnych objektov, interaktívnych vzdelávacích aplikácií na CD a DVD nosičoch, respektíve používajú vo vyučovaní digitálne hračky. Väčšina učitel'ov má k týmto technológiám vysoko pozitívny vzt'ah a reálne ich využíva vo výučbe anglického jazyka.

Čo sa týka výskumnej vzorky, vychádzajúc z našich limitovaných možností uskutočnenia výskumu, uprednostnili sme pri jej vytváraní možnosti dostupnosti nenáhodného výberu pred náhodným výberom. Prihliadajúc na uvedené skutočnosti, sme vytvorili výskumnú vzorku, ktorú tvorili žiaci vekovej úrovne 10 - 15 rokov reprezentujúci nižší sekundárny stupeň.

Výskumnú vzorku tvorí celkovo 126 respondentov - žiakov vekovej úrovne 10 - 15 rokov. Sú to žiaci piateho až deviateho ročníka druhého stupňa Základnej školy, Ulici sv. Michala 42 v Leviciach. Predmet anglický jazyk sa vyučuje povinne $v$ piatom až deviatom ročníku uvedenej ZŠ v časovej dotácii 3 hodiny týždenne.

Základné informácie charakterizujúce vybranú výskumnú vzorku sú sumarizované v tabul'ke 2 .

\begin{tabular}{l} 
Tabul'ka 4 Skladba výskumnej vzorky respondentov \\
FAKTOR POHLAVIE \\
\cline { 3 - 5 }
\end{tabular}

\section{Výskumné metódy a postupy}

Pre naplnenie stanovených ciel'ov a úloh jednotlivých etáp nášho výskumu sme ako hlavnú metódu výskumu použili dotazníkovú metódu. Na zhodnotenie aktuálneho stavu implementácie elektronickej podpory vzdelávania do vyučovania predmetu anglický jazyk na nižšom sekundárnom stupni vzdelávania sme v rámci výskumu ako nástroj zberu výskumných údajov použili špeciálne vytvorený dotazník. Aplikovaný dotazník by mal byt' okrem vyššie uvedeného analyzovat' atraktivitu a 
záujem žiakov o výučbu prostredníctvom týchto technológií. 150 dotazníkov bolo učitel'mi distribuovaných na Základnú školu v Leviciach. Z celkového počtu bolo vyzbieraných 126. Výsledky zistení boli spracované do tabuliek a grafov. Dotazník pozostáva zo 6 položiek, ktoré sú vyjadrené formou výrokov a otázok. Názory respondentov v položkách P1, P2, P4 a P6 sú vyjadrené pomocou sedemstupňovej Likertovej škály, v položke 5 pomocou pät'stupňovej škály. Vyššia miera nesúhlasu s predloženým tvrdením (otázkou) je označená nižšou hodnotou, úplný nesúhlas je označený stupňom 1, vyššia miera súhlasu s predloženým tvrdením (otázkou) je označená vyššou hodnotou, úplný súhlas je označený stupňom 7 (resp. 5). V dotazníkovej položke číslo 3 (P3) vyberali žiaci jednu možnost' z ponúknutých alternatív, ktorá najlepšie vystihovala ich stanovisko.

\section{Analýza a interpretácia výskumných zistení}

Výskumný problém, ktorý sme si v záverečnej práci stanovili, bolo zistit, či učitelia využívajú potenciál digitálnych technológií vo výučbe anglického jazyka na nižšom sekundárnom stupni vzdelávania $\mathrm{z}$ pohl'adu žiakov atraktívnym a zaujímavým spôsobom, ktorý zároveň ul'ahčuje pochopenie preberaného učiva. Prostredníctvom odpovedí respondentov na dotazníkové položky P1 až P6 sme hodnotili postoje a názory žiakov, pričom sme našli odpovede na otázky, aké sú postoje žiakov k osvojovaniu si anglického jazyka prostredníctvom digitálnych technológií na sledovanom stupni vzdelávania. V nadväznosti na uvedené sme teraz schopní rozoznat', či žiaci považujú anglický jazyk za predmet oblúbený alebo neoblúbený, náročný alebo nenáročný, či digitálne technológie používané vo výučbe anglického jazyka ul’ahčujú pochopenie preberaného učiva a či je pre žiakov vyučovanie sledovaného predmetu vd’aka digitálnym technológiám zaujímavé a atraktívne.

Výsledky hodnotení žiakov sú graficky spracované v grafe 1 (Obrázok 1). Ako uvádza Jurčo (Jurco, 1982), vzt’ah k vyučovaciemu predmetu je vlastne vyjadrením postoja, záujmu o daný predmet. Postoj ako jedna zo zložiek motivácie silne ovplyvňuje záujmy žiakov o učebné predmety, ale zároveň aj postoje samotné sú ovplyvnitel'né. Analýzou jednotlivých odpovedí respondentov na položku P1, ale aj nasledujúcich položiek sme sa snažili určit možné príčiny oblúbenosti, resp. neoblúbenosti uvedeného vyučovacieho predmetu $\mathrm{v}$ kontexte využívania digitálnych technológií. Taktiež sme sa snažili zistit', či atraktívnost' učebných pomôcok ovplyvňuje hodnotenia žiakov v kontexte sledovaného.

$\mathrm{Na}$ základe výsledkov odpovedí prezentovaných na $\mathrm{v}$ grafe 1 (Obrázok 1) vidíme, že 44 respondentov z celkového počtu 126 ohodnotilo svoj vzt’ah $\mathrm{k}$ vyučovaciemu predmetu anglický jazyk ako d - ani oblúbený, ani neoblúbený. Toto hodnotenie môžeme považovat' skôr za neutrálne. Avšak až 49 žiakov hodnotilo uvedený predmet skôr pozitívne (vol'ba odpovede a - vel'mi oblúbený, 24 žiakov ako b-oblúbený a 18 žiakov ako c-skôr oblúbený). Môžeme preto konštatovat', že vzt'ah žiakov k vyučovaciemu predmetu anglický jazyk je skôr pozitívny. V tejto chvíli môžeme bez

Slavonic Pedagogical Studies Journal, ISSN 1339-8660, Volume 5 Issue 1, February 2016 
nároku na úplnost' potvrdit' všeobecne proklamovanú skutočnost', že vhodne použité digitálne technológie významne pomáhajú formovat' postoje žiakov k uvedenému vyučovaciemu predmetu.

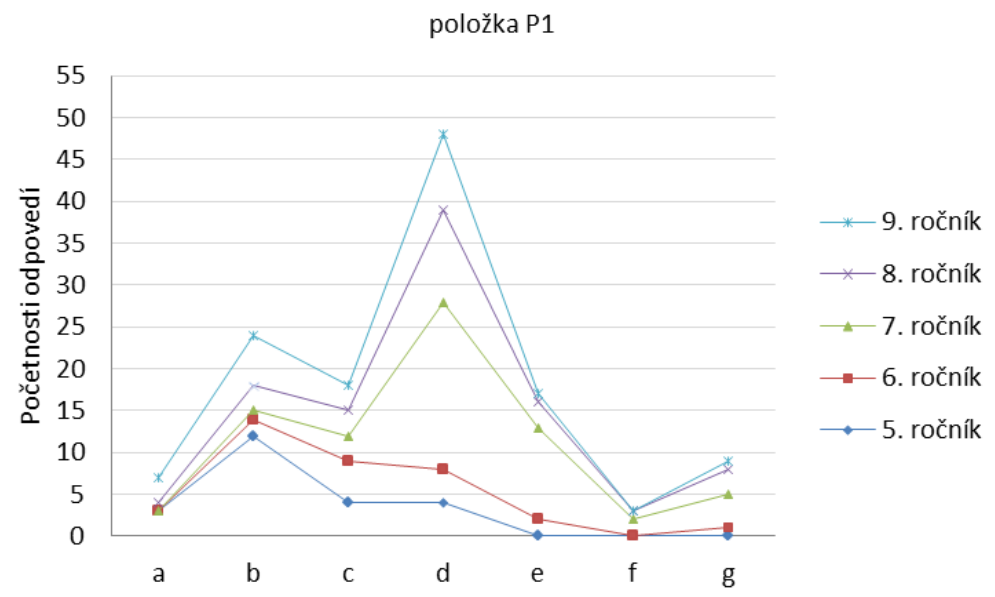

Obrázok 1 Interakčný graf pre položku P1 podl'a faktora POHLAVIE

V položke P2 mali respondenti hodnotit' náročnost' predmetu anglický jazyk (a vel'mi nenáročný, b - nenáročný, c - skôr nenáročný, d - ani náročný, ani nenáročný, e - skôr náročný, f - náročný, g - vel'mi náročný). Z výsledkov tabelovaných v tabul'ke 4 a graficky znázornených v grafe 2 (Obrázok 2) vidíme, že respondenti hodnotili anglický jazyk ako d - ani náročný, ani nenáročný vyučovací predmet. V porovnaní s odpoved'ami respondentov na položku P1, celkovo 45 respondentov je presvedčených, že anglický jazyk patrí medzi f - skôr náročné až $\mathrm{g}$ - vel'mi náročné vyučovacie predmety.

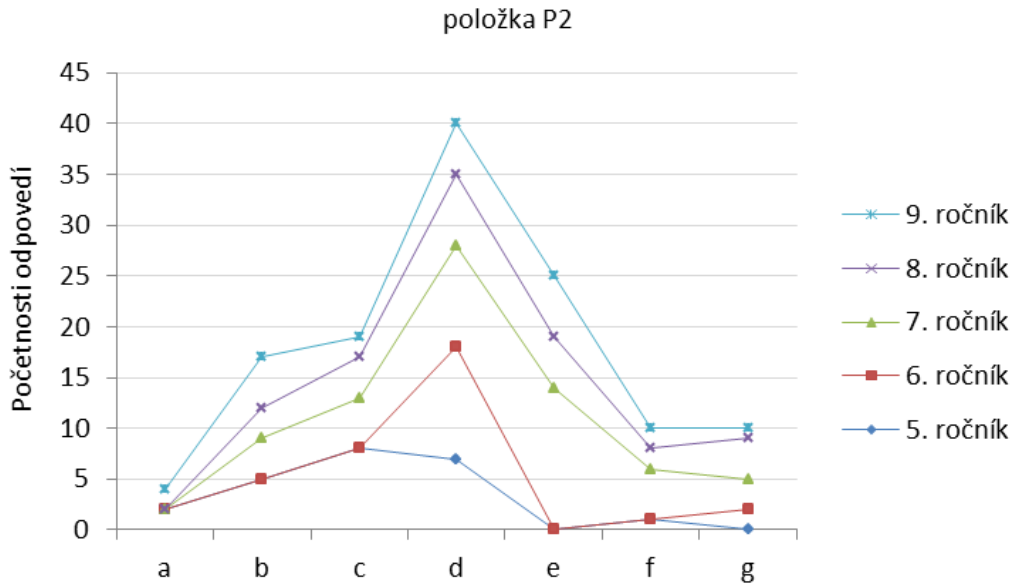

Obrázok 2 Interakčný graf pre položku P2 podl’a faktora POHLAVIE

Položkou P3 sme zist'ovali, aký spôsob výkladu nového učiva žiakom najviac vyhovuje (a - učitel' vysvetl'uje učivo sám, pričom nepoužíva názorné 
učebné pomôcky, b - učitel' vysvetl'uje učivo sám, pričom využíva rôzne učebné pomôcky, c - učitel' zapája do výkladu nového učiva aj žiakov, d učitel' zadá žiakom samostatné úlohy a kontroluje ich postup, e - iný, a to: ...). Výsledky hodnotení ukazujú, že takmer rovnaké množstvo respondentov 53 a 51 potvrdilo, že za najvyhovujúcejší spôsob výkladu nového učiva považujú b - učitel' vysvetl'uje učivo sám, pričom využíva rôzne učebné pomôcky, c - učitel' zapája do výkladu nového učiva aj žiakov. Celkovo môžeme konštatovat', že žiakom 5. až 9. ročníka základnej školy najviac vyhovuje interaktívny spôsob výkladu nového učiva, za čo považujeme ten, pri ktorom sú okrem učitel'a aktívni aj žiaci. Zároveň je z výsledkov hodnotenia tejto položky zrejmá preferencia žiakov k výkladu nového učiva učitel'om samotným a prítomnost'ou učebných pomôcok počas jeho výkladu. $\mathrm{V}$ tejto súvislosti nás zaujímali aj odpovede 6 žiakov, ktorí označili možnost' e - iný, a to:... . Táto skupina žiakov za najvyhovujúcejší spôsob prezentácie nového učiva označila kombináciu možností b a c.

Vzhl'adom k tomu, že pozornost' žiakov nižšieho sekundárneho stupňa vzdelávania vel'mi rýchlo klesá, považujeme digitálne technológie za významný prostriedok, ktorý pomáha vytvorit' motivujúce, zaujímavé, atraktívne vzdelávacie prostredie, ktoré udržuje pozornost' žiakov pri výklade nového učiva. Preto môžeme konštatovat', že digitálne technológie umožňujú žiakom osvojovat' si anglický jazyk vyhovujúcejším spôsobom. $\mathrm{Na}$ kvalitu výsledkov vzdelávacieho procesu má vel'ký vplyv záujem žiakov o učenie, ktorý často závisí aj od spôsobu aplikácie učebných pomôcok vo vzdelávacom procese a tiež od ich rôznorodosti. Skvalitňovanie vybavenosti škôl učebnými pomôckami a ich neustálu modernizáciu je potrebné považovat' za nevyhnutný predpoklad zvyšovania účinnosti vzdelávania a záujmu edukantov o učenie sa anglického jazyka.

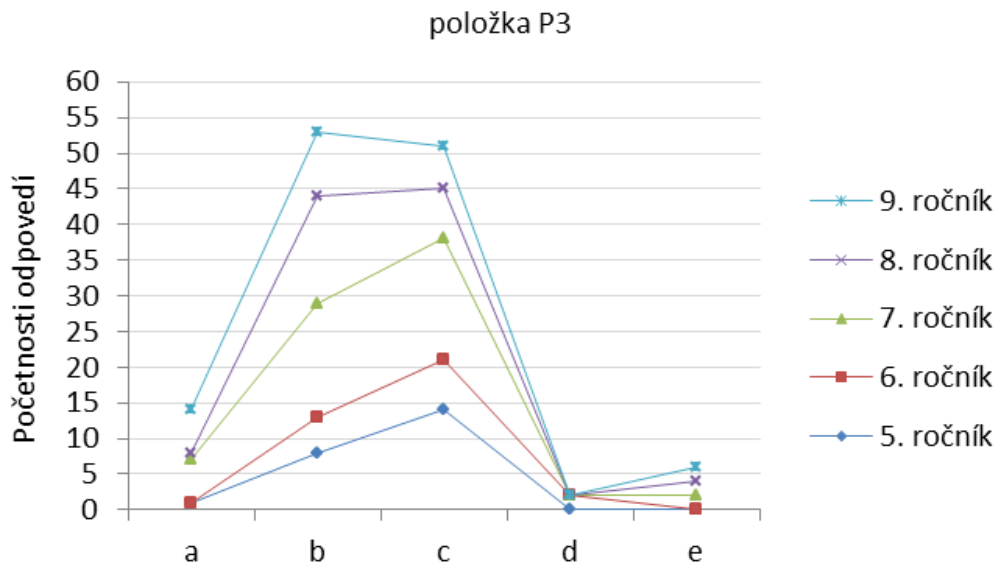

Obrázok 3 Interakčný graf pre položku P3 podl’a faktora POHLAVIE

V položke P4 respondenti hodnotili atraktívnost' digitálnych učebných pomôcok (napr. interaktívnu tabul'u, rôzne vyučovacie programy, 
interaktívne výučbové CD, DVD, internet, digitálne hračky ...) používaných učitel'om na vyučovacích hodinách anglického jazyka ako a - vel'mi zaujímavé, b - zaujímavé, c - skôr zaujímavé, d - ani zaujímavé, ani nezaujímavé, e - skôr nezaujímavé, f - nezaujímavé, g - vel'mi nezaujímavé. Celkovo 46 respondentov ohodnotilo digitálne učebné pomôcky používané počas vyučovacej hodiny anglického jazyka za vel'mi zaujímavé (vol'ba odpovede a). V tejto súvislosti sa 32 respondentov vyjadrilo $\mathrm{k}$ tejto otázke pozitívne a považuje digitálne prostriedky ako b zaujímavé. Len 8 žiakov bolo presvedčených, že uvedené technológie sú podl'a ich názoru f - nezaujímavé a 1 respondent ako g - vel'mi nezaujímavé.

Preto môžeme považovat' za opodstatnené, ked' je vyučovanie a osvojovanie si anglického jazyka realizované s podporou moderných technológií. Veríme, že integrácia týchto prostriedkov pozitívne vplýva na postoje a vzt'ah žiakov nižšieho sekundárneho stupňa $\mathrm{k}$ vyučovaciemu predmetu anglický jazyk. Táto dotazníková položka plní vo vzt'ahu k hlavnému ciel'u našej záverečnej práce významnú úlohu. Pozitívne vyjadrenia respondentov na túto položku považujeme za odrazový mostík. Veríme preto, že má zmysel sa zaoberat' analyzovaním d'alších možností využitia digitálnych technológií vo výučbe anglického jazyka na nižšom sekundárnom stupni vzdelávania.

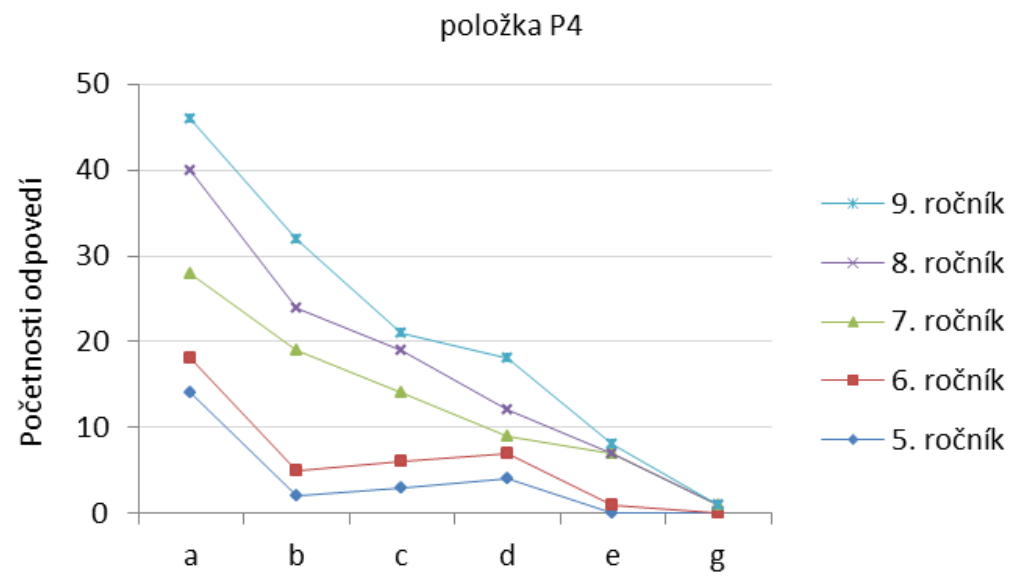

\section{Obrázok 4 Interakčný graf pre položku P4 podl’a faktora POHLAVIE}

V položke P5 sa respondenti vyjadrovali k otázke, či im digitálne technológie používané na vyučovacích hodinách anglického jazyka ul'ahčujú pochopenie preberaného učiva (a - určite áno, b - skôr áno, c ani áno, ani nie, d - skôr nie, e - určite nie). Na základe odpovedí respondentov na túto položku dotazníka sme zistili, že 49 respondentov je presvedčených, že digitálne technológie im počas vyučovania určite pomáhajú (vol'ba odpovede a) pochopit' nové učivo. 46 respondentov zastávalo názor, že im digitálne technológie skôr pomáhajú (vol’ba odpovede b) v pochopení nového vzdelávacieho obsahu. Celkovo môžeme konštatovat', že 95 žiakov malo pozitívny názor v kontexte dotazovaného. 
Preto zastávame názor, že implementácia elektronických prostriedkov vzdelávania do výučby anglického jazyka pomáha učitel'ovi zvyšovat' motiváciu, zlepšuje pochopenie a zapamätanie si nového učiva a rozvíja $u$ žiakov základné jazykové zručnosti. Ako uvádza Pisoňová (Pisonova, 2016: 87), odpoved' na otázku, v čom spočíva pochopenie nového učiva napr. žiakmi v základnej škole, je možné nájst' v požiadavke implementácie analytickej metódy, tzv. metódy Karteziánskeho rozkladu, ktorú zadefinoval Descartes (1970, 1992).

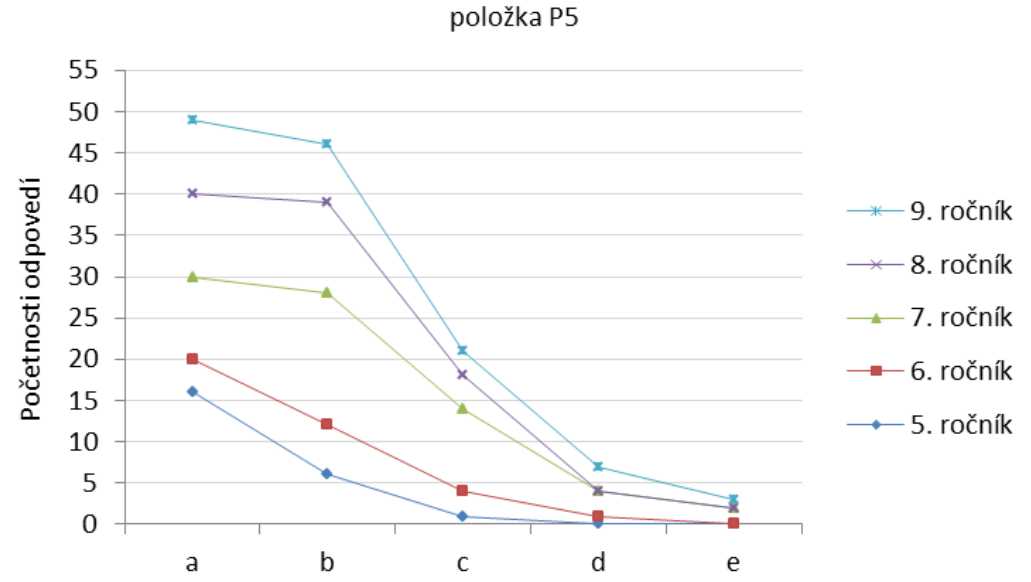

\section{Obrázok 5 Interakčný graf pre položku P5 podl’a faktora POHLAVIE}

V poslednej položke P6 respondenti hodnotili zaujímavost' vyučovacích hodín anglického jazyka, počas ktorých učitel' používa digitálne pomôcky (a vel'mi zaujímavé, b - zaujímavé, c - skôr zaujímavé, d - ani zaujímavé, ani nezaujímavé, e - skôr nezaujímavé, f - nezaujímavé, g - vel'mi nezaujímavé). Výsledky hodnotení tabelovaných v tabul'ke 8 ukazujú, že 40 respondentov je presvedčených, že vd'aka digitálnym prostriedkom sú pre nich vyučovacie hodiny anglického jazyka zaujímavé (b). Dvadsat'devät' respondentov hodnotilo vyučovanie $\mathrm{z}$ tohto pohl'adu za vel'mi zaujímavé (vol'ba alternatívy a) a 28 respondentov ako skôr zaujímavé (vol'ba alternatívy c).

Obsahová náplň vyučovacieho predmetu anglický jazyk je tvorená množstvom takých javov, ktoré sú na úrovni poznania žiaka nižšieho sekundárneho stupňa t'ažko vysvetlitel'né bez názornej demonštrácie. Preto skutočnost', či učitel' používa učebné pomôcky, ktoré a akým spôsobom ovplyvňuje či žiaci považujú hodiny anglického jazyka za zaujímavé. 


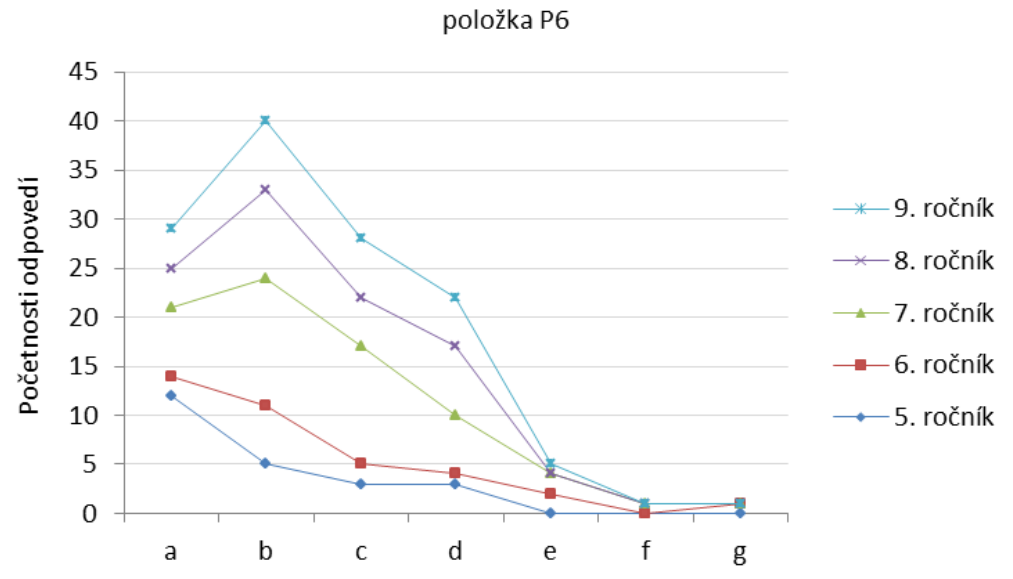

Obrázok 6 Interakčný graf pre položku P6 podl’a faktora POHLAVIE

\section{Záver}

Moderné technológie ovplyvňujú každý aspekt nášho života a vzdelávanie nie je výnimkou. Učitelia majú dostatok možností pre ich využitie vo výučbe, ale je potrebné venovat' náležitú pozornost' i tomu, aby učitel' skutočne používal digitálne technológie zámerne a ciel’avedome so zameraním na rozvoj jazykových zručností.

Technologicky bohaté prostredie samo o sebe nie je zárukou kvalitného využitia digitálnych technológií na podporu poznávacieho procesu žiaka. Ak chceme využit' ich potenciál, vedome a zámerne tým zlepšit' jazykové zručnosti žiakov, učitelia by mali byt' dostatočne kompetentní v zavádzaní digitálnych technológií do výučby anglického jazyka. Nové prostredie reflektuje potreby pedagogiky $\mathrm{v}$ novom tisícročí, ktorá by sa mala zdôrazňovat' flexibilitu, spoluprácu, autentickost', relevantnost', účinnost' a d’alšie faktory potrebné pre úspešné výsledky vzdelávania.

Mnohí autori vo svojej práci uvádzajú, že výučba anglického jazyka žiakov nižšieho sekundárneho stupňa vzdelávania je vel'mi náročná. Pre žiakov v tomto veku je vel'mi dôležité, aby osvojovanie cudzieho jazyka bolo pre nich atraktívne, zaujímavé, hravé, motivujúce a realizované pri tom spôsobom, ktorý si získa ich pozornost' a koreluje s ich očakávaniami $\mathrm{v}$ kontexte vyučovania a učenia sa anglického jazyka. Mnohé štúdie v tejto oblasti ukazujú, že digitálne technológie predstavujú vel'ký potenciál pre splnenie vyššie uvedených očakávaní, požiadaviek žiakov. Výskum sme preto orientovali na analýzu vplyvu hodnotovej orientácie žiakov nižšieho sekundárneho stupňa vzdelávania na vybrané aspekty používania digitálnych technológií vo výučbe anglického jazyka.

$\mathrm{Na}$ základe analýzy výsledkov nášho výskumu môžeme potvrdit', že využívanie moderných technológií vhodným a tvorivým spôsobom zvyšuje motiváciu žiakov. Digitálne technológie sú účinným nástrojom, ktorý pozitívne ovplyvňuje postoje žiakov k osvojovaniu si anglického jazyka. Žiaci si prostredníctvom týchto technológií rozvíjajú svoje jazykové 
zručnosti zaujímavejším a atraktívnejším spôsobom, ktorý zároveň ul'ahčuje pochopenie preberaného učiva.

Záverom môžeme konštatovat', že výsledky nami administrovaného dotazníka potvrdili významný vplyv využívania digitálnych technológií vo výučbe anglického jazyka na úrovni nižšieho sekundárneho vzdelávania.

Veríme, že závery, ku ktorým sme dospeli nájdu svoje uplatnenie v pedagogickom procese a prispejú ku skvalitneniu vyučovania anglického jazyka na základných školách.

\section{Bibliographic references}

AMIRI, E. L. - BRANCH, L. 2002. A Study of The Application of Digital Technologies in Teaching and Learning English Language And Literature. In International Journal of Scientific \& Technology Research, vol. 1, is. 5. Available online: http:/www.docstoc.com/docs/128237832/

DESCARTES, R. 1970. Uvahy o prvni filosofii. Praha: Svoboda. DESCARTES, R. 1992. Rozprava o metode. Praha: Svoboda.

DUCHOVICOVA, J. - SABO, A. - PETROVA, G. 2015. Facilitation of selfconsciousness of academically gifted students [Facilitacia sebavnimania akademicky nadanych ziakov]. In Slavonic Pedagogical Studies Journal, vol. 4. Is. 2. pp. 113-135. ISSN 1339-8660 doi: 10.18355/PG.2015.4.2.113135.

EVANS, M. 2009. Foreign Language Learning with Digital Technology. New York; London: Continuun International Publishing Group [cit. 201502-01]. Available online: books.google.sk/books?isbn=1847060412.

GONZALEZ - LLORET, M. 2010. Brave new digital classroom: Technology and foreign language learning. In Language teaching research, Volume 14, Issue 2, p. 224-227. ISSN: 1362-1688.

HARMER, J. 2005. The Practice of English Language Teaching. 3 ed. Harlow: Pearson Education. p. 370. ISBN 0-582-40385-5.

JURCO, M. 1982. Ucebne predmety ako cinitele motivacie a poznavacich zaujmov ziakov. Psychologia a patopsychologia dietata.

KALAS, I. 2015. Digitalne technologie a vizie moderneho vzdelavania. pp. 3-4 [cit. 2015-01-21]. Available online: http://edi.fmph.uniba. sk/ kalas/publikacie/vizie.doc

LOJOVA, G. 2004. Theory in foreign language teacher training. In Philologica LX. Bratislava: FF UK.

PALENCAROVA, J. - KESSELOVA, J. - KUPCOVA, J. 2011. Ucime slovencinu komunikacne a zazitkovo. In Marciova, M. 2013. Problematika pocuvania s porozumenim v anglickom jazyku. Bratislava: MPC. p. 11. ISBN 978-80-8052-386-2.

PISONOVA, M. 2016. Filozoficka explikacia poziadaviek na proces edukacie - novum alebo prezitok? In XLinguae Journal, Vol. 9 Issue 1, p. 87, ISSN 1337-8384.

POKRIVCAKOVA, S. 2010. Modern teacher of English. Nitra: ASPA. ISBN 978-80-969641-6-1. 
ZAHOREC, J. - HASKOVA. A. - BILEK, M. 2014. Impact of Multimedia Assisted Teaching on Student Attitudes to Science Subjets. In Journal of Baltic Science Education. Vol. 13, No. 3, pp. 361-380. ISSN 1648-3898.

VIALLETON, E. 2012. Foreign Language Learning with Digital Technology. In Language learning \& technology, Volume 16, Issue 2, pp. 27-30. ISSN 1094-3501.

WOOD, J. M. 2000. Literacy: Charlotte's web meets the World Wide Web. In D. T. Gordon (Ed.), The digital classroom: How technology is changing the way we teach and learn. Cambridge, MA: Harvard Education Letter, 2000, pp. 117-126.

Mgr. Adriana Nagyová, PhD.

Comenius University in Bratislava

Department of Education and Social Pedagogy

Račianska 59

81334 Bratislava

Slovakia

nagyova@fedu.uniba.sk 